\title{
Seasonal variation and interaction of photodegradation and microbial metabolism of DOC in black water Amazonian ecosystems
}

\author{
João Henrique F. Amaral ${ }^{1, *}$, Albert L. Suhett ${ }^{2,3}$, Sérgio Melo ${ }^{1,4}$, Vinicius F. Farjalla² \\ ${ }^{1}$ Laboratório de Ecossistemas Aquáticos, Instituto Nacional de Pesquisas da Amazônia INPA-V8, CPEC, Av. Ephigênio Sales, \\ 2239 Aleixo - Manaus, Amazonas 69060-020, Brazil \\ ${ }^{2}$ Laboratório de Limnologia, Depto de Ecologia, Instituto de Biologia, Universidade Federal do Rio de Janeiro, \\ Ilha do Fundão, Rio de Janeiro, Rio de Janeiro 21941-590, Brazil \\ ${ }^{3}$ Present address: Unidade de Biotecnologia e Ciências Biológicas, Centro Universitário Estadual da Zona Oeste, \\ Av. Manuel Caldeira de Alvarenga 1203, Campo Grande, Rio de Janeiro, Rio de Janeiro 23070-200, Brazil \\ ${ }^{4}$ Present address: Instituto de Ciências e Tecnologia das Águas, Universidade Federal do Oeste do Pará, Campus Tapajós, \\ Av. Vera Paz, s/n, Bairro Salé, Santarém, Pará 68035-110, Brazil
}

\begin{abstract}
Photodegradation of dissolved organic carbon (DOC) can generate labile substrates readily available for microbial consumption, thus increasing DOC removal, especially in freshwater humic ecosystems. While a few studies have evaluated the effects of sunlight on DOC removal and $\mathrm{CO}_{2}$ production in aquatic environments, none have investigated the seasonal variation and interaction of photodegradation and microbial metabolism of DOC in a large tropical black-water river system. We present the results of experiments designed to evaluate the rates of photodegradation and subsequent microbial metabolism of DOC in the Negro River and an associated floodplain lake (Lake Tupé) in the central Brazilian Amazon Basin. Water samples collected in both environments at different phases of the river hydrological cycle were filtered and exposed to natural sunlight to estimate photodegradation; they were then inoculated with natural bacteria and incubated in the dark to evaluate bacterial metabolism. Changes in incident solar radiation and in DOC concentration and quality throughout the hydrological cycle directly affected the DOC photodegradation rates and microbial metabolism. Total DOC mineralization (photodegradation plus bacterial consumption) was more intense in the falling water period. DOC photodegradation generally stimulated further microbial DOC degradation, enhancing total DOC removal in samples exposed to solar radiation in both ecosystems. While direct photodegradation represented only a small part of the total DOC mineralization $6.7 \%$ in the high water period in the Negro River), the combined effect of photodegradation and stimulus of bacterial metabolism could account for a significant part of the $\mathrm{CO}_{2}$ production in Amazonian black water ecosystems.
\end{abstract}

KEY WORDS: DOC photodegradation · Bacterial metabolism · Amazon · Carbon mineralization · Seasonality $\cdot$ Hydrological cycle

Resale or republication not permitted without written consent of the publisher

\section{INTRODUCTION}

Whether the Amazon is a modern sink or source of carbon to the global atmosphere is still uncertain. The ongoing debate on this question has led to a series of investigations into the role of natural and anthropogenic processes in Amazonian ecosystems in the regional carbon balance (Nepstad et al. 1994, Fearnside 1997, Engle \& Melack 2000, Kemenes et al. 2007, Houghton et al. 2009). Most aquatic environments in the Amazon have been shown to be supersaturated in $\mathrm{CO}_{2}$, resulting in a regional emis- 
sion of $\sim 500 \mathrm{Tg} \mathrm{C} \mathrm{yr}^{-1}$ to the atmosphere, an order of magnitude higher than the annual export of organic carbon to the ocean (Richey et al. 2002). These high concentrations of dissolved $\mathrm{CO}_{2}$ are apparently derived from the bacterial respiration (BR) of young organic matter (Mayorga et al. 2005), but the contribution of photodegradation and other oxidative processes is yet to be evaluated.

The Negro River is the largest black water tributary of the Amazon River, contributing $~ 14 \%$ of the total discharge and $36 \%$ of the Amazon's total dissolved organic carbon (DOC) flux to the ocean (Richey et al. 1990). Its watershed contains a high density of hydromorphic podzols, which lead to a continuous input of humic-rich DOC to the river system and associated floodplain lakes (Leenheer 1980, Franzinelli \& Igreja 2002). The Negro River main channel and most of its tributaries are considered black-water rivers (Sioli 1984), characterized by high amounts of dissolved humic carbon (up to $90 \%$ of DOC; Moreira-Turcq et al. 2003).

Particularly in humic-rich waters, DOC photodegradation and BR are the main DOC mineralization processes in the water column. Jonsson et al. (2001) reported that microbial respiration and DOC photodegradation together accounted for $70 \%$ of total DOC mineralization in a temperate humic lake. Similar results were reported by Farjalla et al. (2009) for tropical humic freshwater ecosystems. Besides mineralizing DOC directly, photodegradation also stimulates microbial respiration in humic lakes, suggesting that these processes are complementary or linked pathways to DOC mineralization (Amado et al. 2007). In the Negro River, Amon \& Benner (1996) pointed out that at least $15 \%$ of the DOC pool was photoreactive, and Remington et al. (2011) observed high rates of $\mathrm{CO}_{2}$ photoproduction in this same system. Neither study evaluated the seasonal variations of DOC photodegradation and BR as related to the annual hydrological cycle.

Seasonal variations of large Amazon Rivers are mostly driven by the annual flood pulse (Junk et al. 1989). The flood pulse of the Negro River basin is caused by the seasonal variation in precipitation in its watershed and is characterized by 4 distinct hydrological periods: high water, falling water, low water and rising water (Junk et al. 1989). The water level fluctuation from the low water to high water periods in the Negro River main channel can reach up to $15 \mathrm{~m}$ (Latrubesse \& Franzinelli 2005). This hydrological variation affects the biogeochemistry of carbon, resulting in seasonal changes in DOC concentration and composition (Moreira-Turcq et al.
2003, Rodríguez-Zúñiga et al. 2008). Solar radiation also varies seasonally in the Negro River basin, with the highest levels observed in the dry season (Huete et al. 2006), which corresponds to the falling water period in the hydrological cycle. These seasonal changes in carbon biogeochemistry and incident sunlight may influence the rates of DOC photodegradation and its interaction with microbial metabolism, thus affecting total DOC mineralization rates. The aims of the present study were (1) to estimate the potential production of dissolved inorganic carbon (DIC) by DOC photodegradation under natural sunlight exposure, (2) to estimate the consumption of DOC by heterotrophic bacteria and (3) to investigate the response of bacterial metabolism to DOC photodegradation throughout the hydrological cycle in Negro River and an associated floodplain lake (Lake Tupé). Our main hypothesis was that DOC degradation processes, mediated by solar radiation and bacteria, change throughout the hydrological cycle, altering their relative contribution to total DIC generation and total DOC removal.

\section{MATERIALS AND METHODS}

\section{Study site and sampling}

This research was carried out in the lower course of Negro River and an adjacent floodplain lake (Lake Tupé), $26 \mathrm{~km}$ northwest of Manaus, Brazil $\left(3^{\circ} 2^{\prime} 36^{\prime \prime} \mathrm{S}, 60^{\circ} 15^{\prime} 18^{\prime \prime} \mathrm{W}\right)$. The Negro River and Lake Tupé belong to the Negro River watershed and are classified as black water ecosystems. Both water bodies are characterized by low suspended sediment levels and high concentrations of DOC with a predominance of humic substances, which impart a brownish color to these waters (Sioli 1984).

Both sampling sites are subject to an annual flood pulse cycle, characterized by a 10 to $15 \mathrm{~m}$ water level fluctuation (Latrubesse \& Franzinelli 2005). In the high water period, the Negro River floods the surrounding 'igapó' forest and the associated lakes, resulting in a high level of connectivity between these ecosystems (Rai and Hill 1981). The maximum depth of Lake Tupé varies seasonally from 4.5 to $15 \mathrm{~m}$, and its area ranges between 66.9 ha at the low water and 68.0 ha at high water. Though low, this areal variation causes a volume variation as high as $56 \%$, which is a typical phenomenon for 'ria' lakes located in valleys (Rai \& Hill 1981).

Water samples were collected in September 2008, during the falling water period, December 2008 in 
the low water period, April 2009 in the high water period and finally in September 2009 during the falling water period. The water levels were similar in the 2 falling water samplings (Fig. 1). It should be noted that the water level of the Negro River near the sampling stations has been monitored daily since 1903 by the 'Sociedade de Navegação Portos e Hidrovias, Manaus, $\mathrm{AM}^{\prime}$ and that the highest water level ever recorded was registered in 2009 (Fig. 1). Water samples were collected in acid-rinsed polyethylene bottles from the subsurface in the middle of the Negro main channel near Lake Tupé and at the deepest point in Lake Tupé.

In the laboratory, samples were pre-filtered through pre-combusted $\left(450^{\circ}\right.$ to $500^{\circ}$ for $\left.1 \mathrm{~h}\right)$ glass fiber filters (Macherey-Nagel GF-5 filters, of $0.7 \mu \mathrm{m}$ nominal pore size) and then filtered through $0.2 \mu \mathrm{m}$ VacuCap membrane filters (Gelman Science) to eliminate bacteria and other microorganisms. The filtered water was collected in borosilicate bottles (1 1), which were previously cleaned with $\mathrm{HCl}(10 \%)$, washed in Milli$\mathrm{Q}$ water, autoclaved $\left(120^{\circ} \mathrm{C}, 1 \mathrm{~atm}\right)$ and stored in a refrigerator $\left(4^{\circ} \mathrm{C}\right)$ until the next day, when the experiments were conducted.

\section{Experimental design}

For each ecosystem and sampling period, 20 quartz tubes (100 ml capacity) filled with filtered water were exposed to natural sunlight. Prior to exposure, the

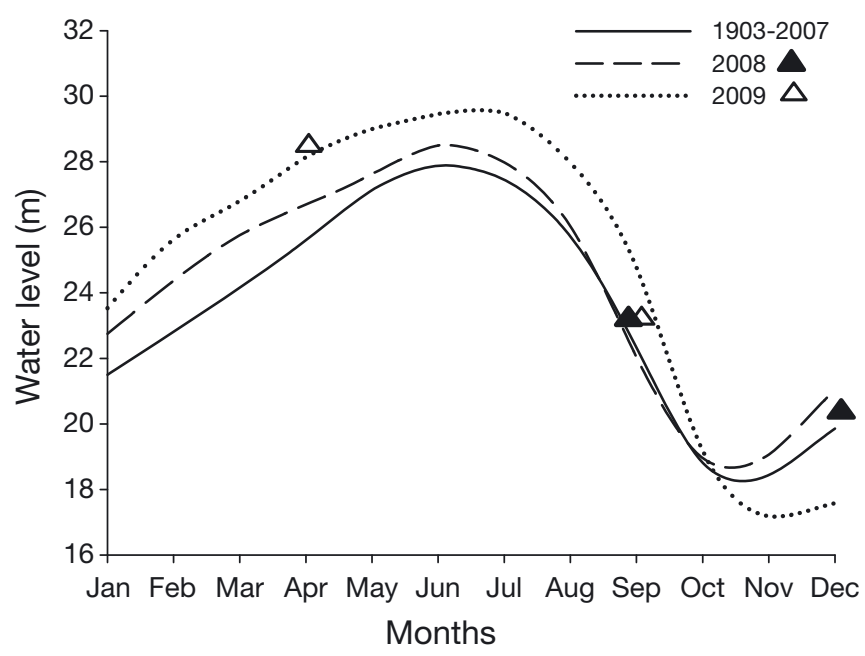

Fig. 1. Variation in the water level (m) of the Negro River, Amazon Basin, Brazil. Solid line: historical monthly mean of water level measured from 1903 and 2007; dashed line: monthly water level of 2008 ; dotted line: monthly water level of 2009. ( $\boldsymbol{\Delta}$ ) the samplings in 2008 (falling water and low water); $(\Delta)$ the samplings in 2009 (high water and falling water) tubes were carefully filled with the $0.2 \mu \mathrm{m}$ filtered water and then sealed, avoiding headspace and bubbles. Because the method used here to evaluate the DOM photodegradation is destructive (see below), we divided the 20 tubes into 2 sets: 10 tubes were used for exclusively evaluating DOC photodegradation, and the other 10 were used to evaluate the effects of DOC photodegradation on DOC consumption by bacteria. Two treatments were established for each set of tubes: exposed tubes $(n=5)$ and control tubes $(\mathrm{n}=5)$; the latter were covered with aluminum foil to exclude the sunlight effects. The quartz tubes were cleaned and sterilized as described in the previous section for the borosilicate bottles.

All tubes were incubated in a water bath under natural sunlight exposure for $6 \mathrm{~h}$ around noon. The temperature of the water bath was kept at $\sim 29^{\circ} \mathrm{C}$ (median annual temperature of the main Amazonian large rivers; see Alin et al. 2011) through constant tap water flow. The total UV-VIS radiation incident on samples $(240$ to $700 \mathrm{~nm}$ ) was estimated by the satellite Radar-GOES at 30 min intervals during incubation time. Irradiance data were provided by the Centro de Previsão de Tempo e Estudos Climáticos Instituto Nacional de Pesquisas Espaciais Brazil (CPTEC-INPE) and integrated over the exposure time.

Initial DOC concentration and water color were evaluated before sunlight incubations. We used water color as an indicator of the amount of humic substances in a water sample (for review, see Vähätalo 2009). After incubations, aliquots for analysis of DIC were collected from the control and exposed treatments, fixed with $\mathrm{HgCl}_{2}(0.01 \%$, final concentration) to stop occasional biological activity and kept refrigerated until analysis. To avoid DIC losses by diffusion, we used a syringe connected to silicone tubing. The tip of the syringe was placed at the bottom of the vial (capacity $25 \mathrm{ml}$ ); the water samples were slowly poured into the vial and each vial was filled to overflowing with at least 3 times its volume. All analyses were performed within 1 wk of the sunlight incubations.

The bacterial batch cultures were set up in $500 \mathrm{ml}$ borosilicate bottles separated by control and exposed treatment for each ecosystem (1 bottle per treatment/ ecosystem). In each bottle, we combined the volume of control or exposed quartz tubes and added a bacterial inoculum. The bacterial inoculum consisted of GF-5 filtered water from each ecosystem $(10 \%$ of total culture volume). Nitrogen $\left(50 \mu \mathrm{M} \mathrm{N}-\mathrm{NH}_{4} \mathrm{NO}_{3}\right)$ and phosphorus $\left(5 \mu \mathrm{M}\right.$ P- $\left.\mathrm{KH}_{2} \mathrm{PO}_{4}\right)$ were added to the cultures to avoid nutrient limitation of bacterial 
growth and to ensure that bacteria responded predominantly to changes in DOC characteristics. The cultures were divided into replicated tubes $(\mathrm{n}=5$, $70 \mathrm{ml}$ each) per treatment for bacterial density and biomass measurements at $0,48,72$ and $96 \mathrm{~h}$ of incubation and into a set of $24 \mathrm{ml}$ vials $(\mathrm{n}=5)$ for the determination of BR. The tubes and vials were kept in the dark for $96 \mathrm{~h}$ at constant temperature $\left(\sim 28^{\circ} \mathrm{C}\right)$. Aliquots for bacterial density and biomass measurements were taken from the tubes at each incubation time and fixed with buffered formalin $(3.7 \%$ final concentration). The set of $24 \mathrm{ml}$ vials was fixed at $96 \mathrm{~h}$ as described above for DIC measurements. BR was estimated from DIC accumulation between 0 and $96 \mathrm{~h}$ as in Amado et al. (2006). We assumed that cumulative BR was linear for calculations of further bacterial parameters.

\section{Analytical methods}

DIC and DOC analyses were performed with a total carbon analyzer that has a $0.01 \mathrm{mg} \mathrm{l}^{-1}$ analytical precision (TOC-VPN, Shimadzu). At least 3 replicate injections were made for each sample, yielding average values with a coefficient of variation $(\mathrm{CV})<2 \%$. DIC photoproduction rates were calculated from the difference between the DIC concentrations in exposed and control samples. We assumed that DOC photodegradation occurred only for $6 \mathrm{~h}$ per day (the incubation time used). This is a conservative approach because we are probably underestimating the process in the Amazon region.

Water color was estimated by the absorbance at $430 \mathrm{~nm}$ and expressed as the absorption coefficient calculated according to $\mathrm{Hu}$ et al. (2002). The samples were analyzed using a Beckman Du 80 spectrophotometer in a $1 \mathrm{~cm}$ quartz cuvette, using distilled water as a blank. To characterize the amount of DOC that was reactive to sunlight, we calculated DOCspecific absorbance expressed as the quotient between water color and DOC concentration measured in each period sampled.

We used the methods proposed by Hobbie et al. (1977) and Fry \& Austin (1988) for obtaining bacterial density and biomass data. Samples stained with acridine orange (final concentration $0.01 \%$ ) were filtered through $0.2 \mu \mathrm{m}$ pore size polycarbonate black membranes (Nucleopore, Whatman), and bacteria were counted and measured using an epifluorescence microscope (Olympus BX 41) equipped with a digital analysis system. Ten pictures were randomly taken at the central portion of each filter. All bacteria in each picture were counted using the software Image Pro Plus ${ }^{\circledR} 6.1$ analysis system (Media Cybernetics). For biomass estimation, we first measured and evaluated the area of 100 cells from the pictures. Then, the cumulative CV was plotted against the number of counted cells, and the point where CV stabilized defined the number of cells to be counted for each sample (Massana et al. 1997). According to this method, we measured 50 cells in each sample using the software Image Pro Plus ${ }^{\circledR}$. The biovolume was estimated as proposed by Fry (1990) and was converted to biomass using the conversion factor of $105 \mathrm{fg} \mathrm{C} \mathrm{mm}^{-3}$ proposed by Theil-Nielsen \& Søndergaard (1998) for bacterial batch cultures.

The evaluated bacterial parameters were the maximum bacterial abundance achieved in the batch cultures (MBA), bacterial production rate (BP), bacterial respiration rate $(\mathrm{BR})$, bacterial DOC removal rate $\left(\mathrm{DOC}_{\mathrm{REM}}\right), \mathrm{DOC}$ bioavailability $\left(\mathrm{DOC}_{\mathrm{L}}\right)$ and bacterial growth efficiency (BGE). BP was estimated as the rate of bacterial biomass accumulation during the exponential growth phase. BR was measured based on the DIC accumulation after incubation for $96 \mathrm{~h}$. DOC $\mathrm{REM}_{\mathrm{R}}$ was calculated as the sum of BR and $\mathrm{BP} . \mathrm{DOC}_{\mathrm{L}}$ was calculated as the percentage of initial DOC that was removed $\left(\mathrm{DOC}_{\mathrm{REM}} / \mathrm{DOC} \times 100\right)$. BGE was calculated as the percentage of $\mathrm{DOC}_{\mathrm{REM}}$ that was incorporated into bacterial biomass (BP/ $\left.\mathrm{DOC}_{\mathrm{REM}} \times 100\right)$.

To estimate the potential DIC production by each process (photodegradation and BR), we calculated rates for $4 \mathrm{~d}$. We calculated the potential DOC photodegradation rate $\left(\mathrm{DOC}_{\mathrm{P}}\right)$ for $96 \mathrm{~h}$ by multiplying the daily rates by 4 , to be comparable to BR. BR was the total BR in $96 \mathrm{~h}$ measured in control samples and the amount of BR enhanced by photodegradation process in the same incubation time.

\section{DOC photodegradation integrated over depth}

We calculated depth-integrated rates of DIC photoproduction for Negro River and Lake Tupé based on the vertical attenuation of sunlight in the water column. We assumed that DIC photoproduction by each wavelength band (UV-B, UV-A and PAR) at a given depth was a fraction of the rates measured in the tubes and was proportional to the extant fraction of incident radiation present at the given depth. First, the measured DIC photoproduction rates were partitioned by each waveband according to the proportional contributions reported by Wang et al. (2009) for humic DOC: 31.8, 32.6 and 25.6\% 
for UV-B, UV-A and PAR, respectively. As we did not measure light attenuation throughout the water column, we estimated attenuation coefficients for each waveband from water color data, according to regression equations derived from data by Granéli et al. (1998) for aquatic ecosystems over a wide water-color range. Integrated DIC photoproduction rates $\left(P_{\text {int }}\right)$ were then calculated for each waveband and summed up, yielding an area-based rate for each ecosystem and sampling period, according to the following equation:

$$
P_{\text {int }}=\sum_{x=\mathrm{UV}-\mathrm{B}}^{\mathrm{PAR}}\left[\frac{P_{x}}{k_{x}}\left(1-\mathrm{e}^{-k_{x} \times z}\right)\right]
$$

where $P_{x}$ is the share of photoproduced DIC by waveband $x$ (in $\left.\mu \mathrm{M} \mathrm{d}^{-1}\right), k_{x}$ is the estimated attenuation coefficient for waveband $x_{1}$ e is the basis of the natural logarithm, and $z$ is the depth in meters. The rates were vertically integrated to the depth where $99 \%$ of the incident radiation had been attenuated. $P_{\text {int }}$ is given in $\mathrm{mmol} \mathrm{C} \mathrm{m} \mathrm{m}^{-2} \mathrm{~d}^{-1}$.

We estimated the contribution of photodegradation to total $\mathrm{CO}_{2}$ evasion by comparing the $P_{\text {int }}$ for the Negro River in the high water period in 2009 to total $\mathrm{CO}_{2}$ efflux calculated after rates measured by Rasera (2010) for the same period, which was the only measurement found for such comparison. Efflux values were calculated for $6 \mathrm{~h}$ to be comparable with DIC photoproduction incubation times. We assumed that all DIC is $\mathrm{CO}_{2}$, due to the low $\mathrm{pH}$ values of Negro River waters.

\section{Statistical analysis}

The effects of sunlight exposure on DOC were tested by comparing each response variable in exposed versus control tubes/flasks with non-paired $t$ tests. The same procedure was used to test the effects of DOC alteration by sunlight on MBA, BP and BR. Variables were log-transformed to conform to the test assumptions whenever necessary. A significance level of $\alpha=0.05$ was used to determine statistical differences. All non-paired $t$-tests were performed using the R language (www.r-project.com) using the package 'nlme'.

\section{RESULTS}

\section{DOC photodegradation and $\mathrm{CO}_{2}$ photoproduction}

DOC concentration, water color, DOC-specific absorbance, the amount of solar radiation during incubations, $\mathrm{CO}_{2}$ photoproduction and precipitation changed seasonally in Negro River and Lake Tupé (Table 1). For both ecosystems, we observed the highest values of water color, DOC-specific absorbance and solar radiation during the falling water period in 2009, with the highest values registered in Negro River, with the exception of DOC-specific absorbance. In Lake Tupé, DOC concentration varied seasonally by $\sim 80 \%$, ranging from $451 \mu \mathrm{M} \mathrm{C}$ at low water to $816 \mu \mathrm{M} \mathrm{C}$ at high water, while this variation was only $10 \%$ in Negro River (737 to $826 \mu \mathrm{M} \mathrm{C}$ ), with the highest value recorded during the falling water period in 2009 (Table 1). The maximum precipitation was registered in the falling water period in 2008 and the lowest in the falling water period in 2009. The highest level of solar radiation was registered during the falling water period in 2009, 45\% higher than the lowest level, recorded in the low water period in 2008 (Table 1).

$\mathrm{CO}_{2}$ concentration in exposed samples was consistently higher ( $t$-test, $\mathrm{p}<0.05)$ compared to controls in Lake Tupé and Negro River for all sampling periods. $\mathrm{CO}_{2}$ photoproduction varied from 19.4 to $151.3 \mu \mathrm{M} \mathrm{C}$ $\mathrm{d}^{-1}$ in Negro River and from 10.0 to $106.2 \mu \mathrm{M} \mathrm{C} \mathrm{d}^{-1}$ in Lake Tupé, with the lowest values recorded in the

Table 1. Dissolved organic carbon (DOC), water color, DOC-specific absorbance, dissolved inorganic carbon (DIC) photoproduction, solar radiation and monthly precipitation throughout the hydrological cycle in the Negro River (NR) and Lake Tupé (LT), Brazil, in 2008 and 2009. We assume that all $\mathrm{DIC}$ is $\mathrm{CO}_{2}$, due to the low pH of Negro River waters; note that $\mathrm{CO}_{2}$ is used in the discussion of the values presented in this table. Values in parentheses represent the standard deviations; nd: not determined

\begin{tabular}{|c|c|c|c|c|c|c|c|c|c|c|c|c|}
\hline \multirow[t]{2}{*}{ Period } & \multicolumn{2}{|c|}{$\begin{array}{c}\text { DOC } \\
(\mu \mathrm{M} \mathrm{C})\end{array}$} & \multicolumn{2}{|c|}{$\begin{array}{l}\text { Water color } \\
\qquad\left(\mathrm{a}_{430}\right)\end{array}$} & \multicolumn{2}{|c|}{$\begin{array}{l}\text { DOC-specific } \\
\text { absorbance } \\
\left(\mathrm{a}_{430}:[\mathrm{DOC}]\right)\end{array}$} & \multicolumn{2}{|c|}{$\begin{array}{c}\text { DIC } \\
\text { photoproduction } \\
\left(\mu \mathrm{M} \mathrm{C} \mathrm{d}^{-1}\right)\end{array}$} & \multicolumn{2}{|c|}{$\begin{array}{l}\text { Integrated DIC } \\
\text { photoproduction } \\
\left(\mathrm{mmol} \mathrm{m}^{-2} \mathrm{~d}^{-1}\right)\end{array}$} & \multirow[t]{2}{*}{$\begin{array}{c}\text { Total } \\
\text { sunlight in } \\
6 \mathrm{~h}\left(\mathrm{~J} \mathrm{~cm}^{-2}\right)\end{array}$} & \multirow[t]{2}{*}{$\begin{array}{l}\text { Precipitation } \\
\left(\mathrm{mm} \mathrm{mo} \mathrm{mo}^{-1}\right)\end{array}$} \\
\hline & NR & $\mathrm{LT}$ & NR & $\mathrm{LT}$ & NR & $\mathrm{LT}$ & NR & LT & NR & $\mathrm{LT}$ & & \\
\hline Falling water 08 & 737 & nd & 20.0 & 7.4 & 0.027 & nd & $29.0(1.8)$ & $14.2(1.8)$ & 5.8 & 4.7 & 918 & 59.4 \\
\hline Low water 08 & 757 & 451 & 8.8 & 1.8 & 0.012 & 0.004 & $19.4(0.18)$ & $10.0(0.7)$ & 5.9 & 4.9 & 829 & 34.4 \\
\hline High water 09 & 815 & 816 & 11.8 & 10.8 & 0.015 & 0.013 & $42.0(7.1)$ & $44.0(1.6)$ & 11.4 & 12.4 & 876 & 40.9 \\
\hline Falling water 09 & 826 & 563 & 22.8 & 20.6 & 0.028 & 0.037 & $151.3(5.9)$ & $106.2(11.2)$ & 27.9 & 20.9 & 1203 & 3.1 \\
\hline
\end{tabular}


low water period and the highest values recorded in the falling water period in 2009 for both sampling sites (Table 1). $\mathrm{CO}_{2}$ photoproduction rates were similar in both environments at high water: $42.0 \mu \mathrm{M} \mathrm{C} \mathrm{d}^{-1}$ for Negro River and $44.0 \mu \mathrm{M} \mathrm{C} \mathrm{d}^{-1}$ for Lake Tupé. It is worth noting that the same trend was recorded for water color and DOC concentration (Table 1). When integrated over depth, $\mathrm{CO}_{2}$ photoproduction rates were quite similar between falling water (Negro River: $5.8 \mathrm{mmol} \mathrm{C} \mathrm{d}^{-2}$; Lake Tupé: $\left.4.7 \mathrm{mmol} \mathrm{C} \mathrm{d}^{-2}\right)$ and low water (Negro River: $5.9 \mathrm{mmol} \mathrm{C} \mathrm{d}^{-2}$; Lake Tupé: $4.9 \mathrm{mmol} \mathrm{C} \mathrm{d}^{-2}$ ) in 2008 for both environments (Table 1). However, integrated $\mathrm{CO}_{2}$ photoproduction rates were twice as high at high water (Negro River: 11.4 $\mathrm{mmol} \mathrm{C} \mathrm{d}^{-2}$; Lake Tupé: $12.4 \mathrm{mmol} \mathrm{C} \mathrm{d}^{-2}$ ) and 5-fold higher during falling water (Negro River: $27.9 \mathrm{mmol} \mathrm{C} \mathrm{d}^{-2}$; Lake Tupé: $20.9 \mathrm{mmol} \mathrm{C} \mathrm{d}^{-2}$ ) in 2009 compared to those measured at low water (Table 1).

\section{Microbial response to DOC photodegradation and the combined contribution to $\mathrm{CO}_{2}$ production}

Sunlight stimulated the increase of bacterial abundance in Negro River and Lake Tupé in all sampling periods, except for the high water period in 2009 in
Negro River ( $t$-test, p $<0.05$, Table 2). Sunlight increased MBA in Negro River by $94 \%$ to $>200 \%$ relative to dark controls in the falling water period in 2008 and the high water period in 2009 , respectively (Table 2). In Lake Tupé, MBA was $76 \%$ greater in exposed samples at high water and $50 \%$ greater at low water (Table 2).

BP in Negro River was enhanced by DOC photodegradation only in the falling water period in 2008 (84\% increase in relation to control samples, $t$-test, $\mathrm{p}<0.05$, Table 2), while BR was stimulated in the falling water and in the low water periods of 2008 ( $t$-test, $\mathrm{p}<0.05$, Table 2). In Lake Tupé, BP was not affected by DOC exposure to sunlight in any period, while BR increased in all sampling periods, except for the high water period in 2009 ( $t$-test, $\mathrm{p}<0.05$, Table 2). In general, for Negro River, BGE was higher in exposed samples than in controls, except for the low water period, when prior exposure of DOC to sunlight decreased BGE by $\sim 67 \%$ (Table 2). In contrast, BGE was lower in exposed samples in relation to controls in Lake Tupé, except in the high water period, when an increment of $21 \%$ was registered in $\mathrm{BGE}$ in exposed samples in relation to controls.

Bacterial DOC removal (BP + BR) and DOC availability $\left(\mathrm{DOC}_{\mathrm{L}}\right)$ were stimulated by photodegradation

Table 2. Maximum bacterial abundance (MBA), bacterial production rates (BP), bacterial respiration rate (BR), bacterial DOC removal $\left(\mathrm{DOC}_{\mathrm{REM}}\right)$, percentage of bulk DOC available to bacterial consumption $\left(\mathrm{DOC}_{\mathrm{L}}\right)$ and bacterial growth efficiency $(\mathrm{BGE})$ estimated for the Negro River and Lake Tupé bacterial cultures (sunlight exposed and control) during the 4 sampling periods (falling water 2008, low water 2008, high water 2009 and falling water 2009) of the hydrological cycle. Values in parentheses represent the standard deviations. Different capital letters (A, B) indicate significant differences between exposed and control samples; nd: not determined

\begin{tabular}{|c|c|c|c|c|c|c|c|}
\hline $\begin{array}{l}\text { Location } \\
\text { Period }\end{array}$ & Treatment & $\begin{array}{c}\text { MBA } \\
\left(10^{10}{\left.\text { cells } ~^{-1}\right)}^{-1}\right.\end{array}$ & $\begin{array}{c}\text { BP } \\
\left(\mu \mathrm{M} \mathrm{C}^{-1}\right)\end{array}$ & $\begin{array}{c}\mathrm{BR} \\
\left(\mu \mathrm{M} \mathrm{C}^{-1}\right)\end{array}$ & $\begin{array}{c}\mathrm{DOC}_{\mathrm{REM}} \\
\left(\mu \mathrm{MC} 96 \mathrm{~h}^{-1}\right)\end{array}$ & $\begin{array}{c}\mathrm{DOC}_{\mathrm{L}} \\
(\%)\end{array}$ & $\begin{array}{c}\text { BGE } \\
(\%)\end{array}$ \\
\hline \multicolumn{8}{|l|}{ Negro River } \\
\hline Falling water 08 & $\begin{array}{l}\text { Control } \\
\text { Exposed }\end{array}$ & $\begin{array}{l}0.58(0.28)^{\mathrm{A}} \\
1.13(0.23)^{\mathrm{B}}\end{array}$ & $\begin{array}{l}0.25(0.05)^{\mathrm{A}} \\
0.46(0.14)^{\mathrm{B}}\end{array}$ & $\begin{array}{l}0.58(0.42)^{\mathrm{A}} \\
0.81(0.46)^{\mathrm{B}}\end{array}$ & $\begin{array}{c}79.2 \\
121.4\end{array}$ & $\begin{array}{l}11 \\
17\end{array}$ & $\begin{array}{l}30 \\
36\end{array}$ \\
\hline Low water 08 & $\begin{array}{l}\text { Control } \\
\text { Exposed }\end{array}$ & $\begin{array}{l}0.68(0.11)^{\mathrm{A}} \\
2.07(0.31)^{\mathrm{B}}\end{array}$ & $\begin{array}{l}0.33(0.24)^{\mathrm{A}} \\
0.20(0.12)^{\mathrm{A}}\end{array}$ & $\begin{array}{l}0.10(0.01)^{\mathrm{A}} \\
0.27(0.01)^{\mathrm{B}}\end{array}$ & $\begin{array}{l}34.0 \\
41.2\end{array}$ & $\begin{array}{l}5 \\
5\end{array}$ & $\begin{array}{l}76 \\
25\end{array}$ \\
\hline High water 09 & $\begin{array}{l}\text { Control } \\
\text { Exposed }\end{array}$ & $\begin{array}{l}1.03(0.27)^{\mathrm{A}} \\
1.23(0.13)^{\mathrm{A}}\end{array}$ & $\begin{array}{l}0.67(0.30)^{\mathrm{A}} \\
0.89(0.20)^{\mathrm{A}}\end{array}$ & $\begin{array}{l}1.48(0.03)^{\mathrm{A}} \\
1.56(0.01)^{\mathrm{A}}\end{array}$ & $\begin{array}{l}206.3 \\
235.6\end{array}$ & $\begin{array}{l}26 \\
30\end{array}$ & $\begin{array}{l}31 \\
36\end{array}$ \\
\hline Falling water 09 & $\begin{array}{l}\text { Control } \\
\text { Exposed }\end{array}$ & $\begin{array}{l}0.74(0.07)^{\mathrm{A}} \\
1.55(0.25)^{\mathrm{B}}\end{array}$ & $\begin{array}{l}0.64(0.45)^{\mathrm{A}} \\
1.04(0.49)^{\mathrm{A}}\end{array}$ & $\begin{array}{l}2.06(1.50)^{\mathrm{A}} \\
3.04(1.50)^{\mathrm{A}}\end{array}$ & $\begin{array}{l}259.7 \\
392.0\end{array}$ & $\begin{array}{l}33 \\
54\end{array}$ & $\begin{array}{l}24 \\
26\end{array}$ \\
\hline Lake Tupé & & & & & & & \\
\hline Falling water 08 & $\begin{array}{l}\text { Control } \\
\text { Exposed }\end{array}$ & $\begin{array}{l}0.53(0.01)^{\mathrm{A}} \\
1.24(0.29)^{\mathrm{B}}\end{array}$ & $\begin{array}{l}0.27(0.30)^{\mathrm{A}} \\
0.40(0.24)^{\mathrm{A}}\end{array}$ & $\begin{array}{l}0.19(0.05)^{\mathrm{A}} \\
0.44(0.05)^{\mathrm{B}}\end{array}$ & $\begin{array}{l}44.6 \\
80.2\end{array}$ & nd & $\begin{array}{l}59 \\
47\end{array}$ \\
\hline Low water 08 & $\begin{array}{l}\text { Control } \\
\text { Exposed }\end{array}$ & $\begin{array}{l}0.37(0.12)^{\mathrm{A}} \\
0.73(0.09)^{\mathrm{B}}\end{array}$ & $\begin{array}{l}0.18(0.09)^{\mathrm{A}} \\
0.21(0.07)^{\mathrm{A}}\end{array}$ & $\begin{array}{l}0.12(0.02)^{\mathrm{A}} \\
0.21(0.03)^{\mathrm{B}}\end{array}$ & $\begin{array}{l}29.3 \\
40.8\end{array}$ & $\begin{array}{l}7 \\
9\end{array}$ & $\begin{array}{l}60 \\
50\end{array}$ \\
\hline High water 09 & $\begin{array}{c}\text { Control } \\
\text { Exposed }\end{array}$ & $\begin{array}{l}1.97(0.27)^{\mathrm{B}} \\
2.58(0.86)^{\mathrm{A}}\end{array}$ & $\begin{array}{l}1.31(0.42)^{\mathrm{A}} \\
1.76(1.06)^{\mathrm{A}}\end{array}$ & $\begin{array}{l}1.44(0.05)^{\mathrm{A}} \\
1.28(0.03)^{\mathrm{A}}\end{array}$ & $\begin{array}{l}263.7 \\
292.0\end{array}$ & $\begin{array}{l}29 \\
36\end{array}$ & $\begin{array}{l}48 \\
58\end{array}$ \\
\hline Falling water 09 & $\begin{array}{l}\text { Control } \\
\text { Exposed }\end{array}$ & $\begin{array}{l}0.56(0.08)^{\mathrm{A}} \\
0.64(0.10)^{\mathrm{B}}\end{array}$ & $\begin{array}{c}0.27(0.07)^{\mathrm{A}} \\
0.48(0.18)^{\mathrm{A}}\end{array}$ & $\begin{array}{l}0.78(0.50)^{\mathrm{A}} \\
1.49(1.25)^{\mathrm{B}}\end{array}$ & $\begin{array}{l}100.3 \\
184.3\end{array}$ & $\begin{array}{l}17 \\
33\end{array}$ & $\begin{array}{l}26 \\
22\end{array}$ \\
\hline
\end{tabular}


in all sampling periods in both ecosystems (Table 2), except for $\mathrm{DOC}_{\mathrm{L}}$ in Negro River, which presented the same value $(5 \%)$ in exposed and control samples during the low water period. The largest increments of bacterial DOC removal by photodegradation stimulation were registered in the falling water periods, being $53 \%$ in 2008 and $50 \%$ in 2009 for Negro River (Table 2) and $80 \%$ in 2008 and $84 \%$ in 2009 for Lake Tupé (Table 2). The same trend was observed for DOC $_{\mathrm{L}}$, with an increase of $55 \%$ in exposed samples in the falling water in 2008 and $63 \%$ during falling water in 2009 for the Negro River. For Lake Tupé, a $94 \%$ increment was observed in $\mathrm{DOC}_{\mathrm{L}}$ during the falling water period in 2009.

Potential $\mathrm{CO}_{2}$ production $\left(\mathrm{DOC}_{\mathrm{P}}+\mathrm{BR}\right)$ differed seasonally in both ecosystems (Fig. 2). The highest total $\mathrm{CO}_{2}$ production was registered in the falling water period in 2009 followed by the high water period in Negro River and Lake Tupé. $\mathrm{DOC}_{\mathrm{P}}$ was responsible for the majority of $\mathrm{CO}_{2}$ production $(>60 \%)$ in almost all sampling periods in Negro River, except for the high water period, when total BR and $\mathrm{DOC}_{\mathrm{P}}$ had similar participation in total $\mathrm{CO}_{2}$ production (Fig. 2A). In Lake Tupé, $\mathrm{DOC}_{\mathrm{P}}$ accounted for $75 \%$ of total $\mathrm{CO}_{2}$ production in the falling water period in 2009 and $67 \%$ in the low water period. The contribution of total BR to $\mathrm{CO}_{2}$ production (Fig. 2B) in the high water period and in the falling water of 2008 was similar ( $43 \%$ and $44 \%$, respectively). Finally, the $\mathrm{CO}_{2}$ photoproduction integrated over depth
(11.4 $\mathrm{mmol} \mathrm{m} \mathrm{m}^{-2} \mathrm{~d}^{-1}$ ) accounted for $6.7 \%$ of the total $\mathrm{CO}_{2}$ efflux (168.4 $\mathrm{mmol} \mathrm{m}^{-2} \mathrm{~d}^{-1}$ ) from Negro River to the atmosphere at the high water period in 2009.

\section{DISCUSSION}

The results reported here corroborate our hypothesis that changes in the incidence of solar radiation and DOC concentration and quality throughout the hydrological cycle directly affect the DOC photodegradation rates and the microbial metabolism in this Amazonian black-water ecosystem. In general, DOC photodegradation stimulated posterior microbial DOC degradation, enhancing the total DOC removal in samples exposed to solar radiation for both ecosystems. Thus, even though depth-integrated $\mathrm{CO}_{2}$ photoproduction was proportionally low (6.7 \% of the total $\mathrm{CO}_{2}$ efflux in the high water period in the Negro River), the combined effect of photodegradation and stimulus of bacterial metabolism could account for a significant part of the $\mathrm{CO}_{2}$ production in these black-water environments.

\section{DOC photodegradation and $\mathrm{CO}_{2}$ photoproduction}

It is well established that humic substances are reactive to photodegradation (Bertilsson \& Tranvik 2000, Farjalla et al. 2009), and the DOC from the
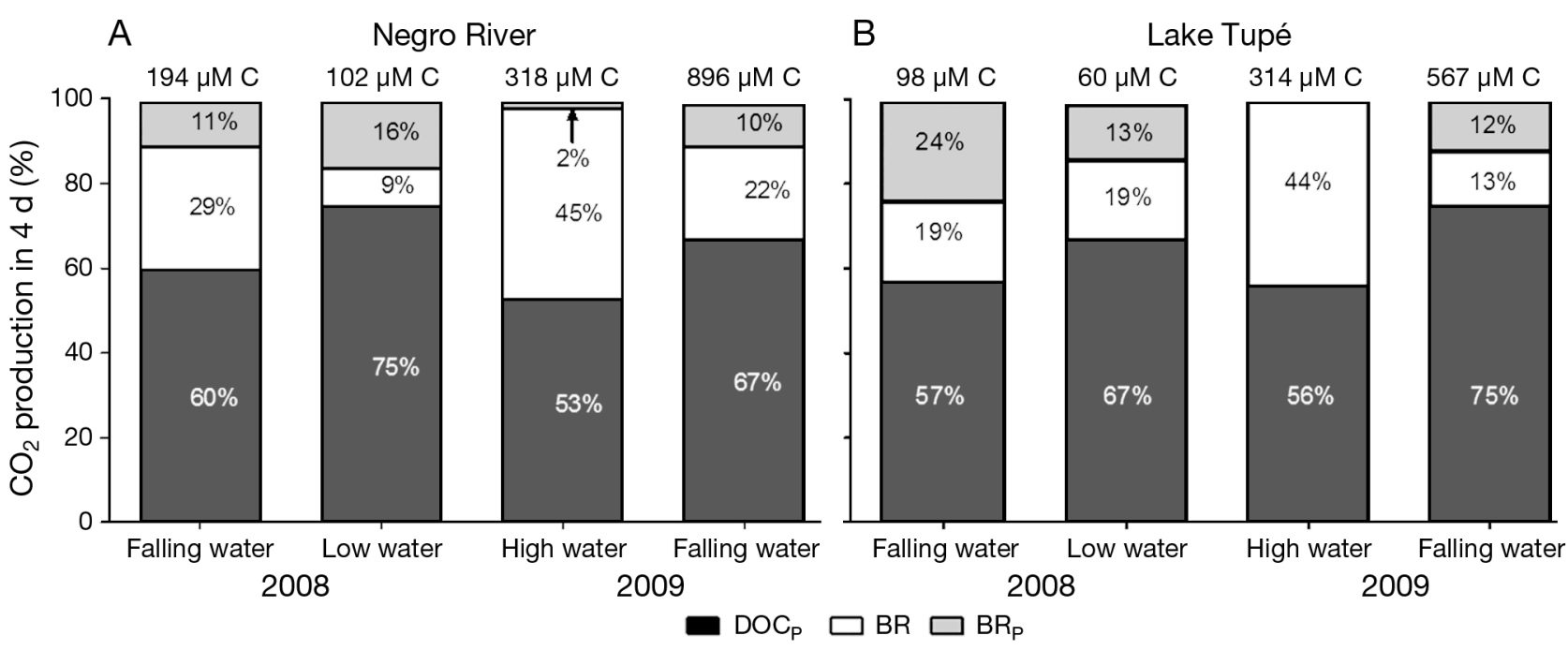

Fig. 2. Photoproduced DIC $\left(\mathrm{DOC}_{\mathrm{P}}\right)$, bacterial respiration $(\mathrm{BR})$ and bacterial respiration enhanced by photodegradation $\left(\mathrm{BR}_{\mathrm{P}}\right)$ in (A) Negro River and (B) Lake Tupé during the 4 sampling periods (falling water 2008, low water 2008, high water 2009 and falling water 2009). All values were estimated for $4 \mathrm{~d}$, based on $24 \mathrm{~h}$ per day for BR and $6 \mathrm{~h}$ per day for DOC $\mathrm{P}_{\mathrm{P}}$. For this calculation, we only considered the subsurface water, where the photochemistry is not altered by attenuation of sunlight in the water column. Values above the bars are the total DIC $(\mu \mathrm{M} \mathrm{C})$ produced in $4 \mathrm{~d}$. Percentages are representative for the total DIC values in each period 
Negro River and Lake Tupé is predominantly composed of very photoreactive humic substances (Ertel et al. 1986, Hedges et al. 1994, Amon \& Benner 1996, Rodríguez-Zúñiga et al. 2008). A positive relationship between DOC photodegradation rates and the intensity of incident radiation is usually observed (de Haan 1993, Bertilsson \& Tranvik 2000, Farjalla et al. 2001). Seasonally, in a highly humic coastal lagoon, the highest DOC photodegradation rates were recorded when the incidence of solar radiation was maximal and water color values were the highest (Suhett et al. 2007). Therefore, it is not surprising that the highest DOC photodegradation rates observed here were recorded in the falling water period (2009), when both incident radiation and water color were the highest among the sampling periods. These factors may have interacted, resulting in atypically high photodegradation rates (151.3 and 106.2 $\mu \mathrm{M} \mathrm{C}$ $\mathrm{d}^{-1}$ for Negro River and Lake Tupé, respectively) only comparable to rates found in other tropical humic ecosystems (>80 $\mathrm{MM} \mathrm{C} \mathrm{d}^{-1}$; for review, see Farjalla et al. 2009) .

The flood pulse determines the major sources of organic carbon and the connectivity between Amazonian aquatic ecosystems (e.g. Farjalla et al. 2006), and those factors regulate the differences in the abiotic conditions and DOC photodegradation rates. The input of allochthonous, humic-rich carbon from the watershed increases during the annual flood, while the production of autochthonous carbon is usually greater in the low water period (Farjalla et al. 2006). For example, Rai \& Hill (1981) observed the maximum chlorophyll a concentrations in Lake Tupé in the low water period, due to an increase in water transparency. Humic DOC is more available to photodegradation than algal DOC (Tranvik \& Bertilsson 2001, Amado et al. 2006). Thus, it is not surprising that we observed the highest DOC photodegradation rates in Lake Tupé during the annual flood and the lowest ones during the low water period (Table 1). A similar pattern was not found in the Negro River (Table 1), possibly due its turbulent regime that reduces the development of phytoplankton communities. Also, the increased connectivity during the annual flood homogenizes the abiotic conditions (Rai \& Hill 1981) and the potential DOC photodegradation. In the high water period, water color, DOC concentration and DOC photodegradation rates were similar between environments (Table 1), showing that they have similar water characteristics and potential for photodegradation. In contrast, the greatest differences of water color, DOC concentration and DOC photodegrada- tion rates between Negro River and Lake Tupé were observed in the low water period (Table 1), when the connectivity between the ecosystems was low and they were subjected to different structuring forces.

The differences in photodegradation rates between the falling water periods in 2008 and 2009 seem to reflect annual differences in the hydrological cycle. The 2009 flood was atypically high (the highest ever recorded for Negro River; Fig. 1). Possibly, a greater amount of photoreactive DOC was carried from the floodplain through both ecosystems compared to the flood in 2008. Furthermore, the difference registered in solar incidence $(31 \%$ greater in 2009) was more determinant of the recorded $\mathrm{CO}_{2}$ photoproduction rates in the falling water periods than water color was; water color values were comparable for falling water in both sampled years. We also highlight the fact that both volume-based and integrated photodegradation rates showed very similar patterns for both environments (Table 1). This means that the potential of more colored DOC to increase sunlight attenuation down the water column was not sufficient to cause considerable changes (even inversions) in the patterns observed for volume-based rates when they were depth-integrated.

\section{Microbial response to DOC photodegradation and the combined contribution to $\mathrm{CO}_{2}$ production}

There is usually a synergism between DOC photodegradation and bacterial DOC consumption in humic ecosystems, due to the photochemical release of labile molecules to bacteria (Bertilsson \& Tranvik 2000, Farjalla et al. 2009). This pattern was particularly remarkable during the falling water periods of 2008 and 2009, in which both ecosystems showed the highest increments of BP and/or BR in exposed samples (Table 2). The falling water period in the flood pulse is characterized by high concentrations of humic DOC (see Table 1 and Moreira-Turcq et al. 2003) and the highest DOC photodegradation rates (Table 1). DOC photodegradation greatly stimulates the subsequent bacterial metabolism in humic systems, through the release of labile carbon molecules from the refractory bulk DOC (Tranvik \& Bertilsson 2001). Therefore, the highest DOC photodegradation rates associated with the dominance of humic compounds in the bulk DOC resulted in the highest rates of bacterial metabolism after sunlight exposure in the falling water periods. 
No clear effect of DOC photodegradation on bacterial processes was observed for Negro River or Lake Tupé during the high water period (Table 2), when the input of allochthonous humic carbon was high and we would expect a positive relation between both processes. A similar pattern was previously found in the region; this was attributed to limitations of the experimental design used or to methodological problems related to the use of Pyrex bottles, which block most UV radiation (Amon \& Benner 1996). Here, we used quartz tubes for the light incubations, and we found similar results, excluding the hypotheses of methodological issues. We suggest that the absence of a bacterial response to DOC photodegradation at high water could reflect the greater availability of fresh DOC from the flooded igapó forest and the watershed at this time (Junk et al. 1989, Benner et al. 1995). In this period, we observed higher values of $\mathrm{DOC}_{\mathrm{L}}$ for Negro River and Lake Tupé compared to the falling water and low water periods in 2008 (Table 2). Furthermore, in a similar study in Negro River with addition of glucose (a labile substrate for microbial metabolism), the authors reported no stimulus in bacterial metabolism either in exposed samples or in controls, indicating that the availability of labile carbon was not limiting bacterial metabolism in the high water period in the Negro River (Amon \& Benner 1996). It is important to highlight that bacterial degradation could conversely affect DOC susceptibility to DOC photodegradation (e.g. Obernosterer \& Benner 2004, Amado et al. 2007), but this aspect was not covered by our experimental design. Nevertheless, we believe this was not a major limitation of our experiments because this kind of effect is less relevant in humic ecosystems, where DOC is intrinsically photoreactive and less labile to bacteria than in systems dominated by algal DOC (see Amado et al. 2007).

BGE indicates the importance of bacteria as a sink or source of carbon to higher trophic levels, i.e. if BGE is high, a greater part of the DOC assimilated by bacteria is converted into bacterial biomass, while if BGE is low, more of the DOC assimilated by bacteria is converted into $\mathrm{CO}_{2}$ through BR. BGE was stimulated by DOC photodegradation in all sampling periods in the Negro River, except at low water, when a decrease in BGE values was recorded after sunlight exposure (Table 2). In contrast, BGE declined following DOC photodegradation in all sampling periods in Lake Tupé, except at high water, when Lake Tupé was greatly influenced by the Negro River (Table 2). It appears that the photodegradation of humic-rich DOC stimulates $\mathrm{BP}$ more than $\mathrm{BR}$, resulting in an increase in BGE (Anesio et al. 2005), but the opposite pattern might occur when the proportion of labile carbon compounds in the DOC pool increases (Amado et al. 2006). The decreases registered in BGE values for Lake Tupé could be due to the formation of reactive oxygen species as a by-product of DOC photodegradation reactions (e.g. hydrogen peroxide), which could impair bacterial growth, increasing more BR than BP (see Pullin et al. 2004). Jardim et al. (2010) reported that there is more hydrogen peroxide available in Negro River in the low water period, which is the only period when we did not record increases in BGE after DOC photodegradation. This could explain the reduction in BP observed and the greater increase in BR in exposed samples. However, changes in BGE after sunlight exposure are difficult to predict since BP and BR may be simultaneously stimulated or inhibited by sunlight exposure, depending on the relative contribution of labile and refractory carbon compounds to the bulk DOC (Amado et al. 2007).

We found seasonal differences in total DIC production by photodegradation and microbial respiration (Fig. 2). For instance, total DIC production during the falling water period in 2009 was 8-fold higher than in the low water period in Negro River and 5-fold higher than in the falling water period in 2008, when the water level was the same and the water color was as high as that recorded in 2009 (Fig. 2). These seasonal and inter-annual differences in photodegradation and microbial respiration rates were explained by differences in the amount of solar radiation, water color and DOC concentration and quality among sampling periods (see 'DOC photodegradation and $\mathrm{CO}_{2}$ photoproduction').

Our estimate of $6.7 \%$ of total $\mathrm{CO}_{2}$ evasion due to photodegradation of DOC (high water period, 2009) was 2-fold higher than the 3\% value reported by Amon \& Benner (1996) for the same period and $\sim 15$-fold higher than the $0.5 \%$ contribution of DOC photodegradation to total DOC mineralization measured in the Negro River in the low water period (Remington et al. 2011). Although DOC photodegradation represents a small part of total DOC mineralization, its subsequent stimulation of bacterial DOC removal could be extensive and more relevant than was previously thought.

It should be noted that the volume-based photodegradation rates in our experiments were potential ones because they do not account for light attenuation down the water column. Therefore, the relative importance of photochemical and bacterial mineralization to total DOC mineralization (depicted in Fig. 2) is 
certainly overestimated. A more accurate estimate of the actual relative contributions of each process to DOC mineralization would be extremely complex for such systems, for several reasons. For instance, we do not know how the photoalteration of DOC lability to bacteria would act at varying depths and how this would affect $B R$ due to photodegradation $\left(\mathrm{BR}_{\mathrm{P}}\right)$ along the water column. Also, the turbulent regime of the Negro River probably leads to a constant mixing of DOC (including photoaltered DOC) into deeper layers of the water column, altering DOC lability irrespective of light penetration. However, with this analysis, we aimed primarily at observing how the potential roles of these processes to mineralize DOC changed over the hydrological cycle.

We assumed that DOC photodegradation is a linear process to make comparisons with bacterial DOC degradation over $4 \mathrm{~d}$ (96 h). This might imply overestimated photochemical DOC removal rates because we did not measure total DOC photoreactivity over 96 h. However, DOC from the Negro River is very photoreactive, maintaining high rates of DOC photodegradation for a $3 \mathrm{~d}$ incubation under natural solar radiation exposure (Amon \& Benner 1996). Also, the constant mixing of the water column due to turbulence and wind action would constantly deliver photoreactive DOC from higher depths to the surface, allowing potentially high, volume-based, photodegradation rates at the surface. Thus, the seemingly high rates of DOC photochemical mineralization for $96 \mathrm{~h}$ are likely valid for the intended comparison made here but should be viewed with caution as actual estimates of ultimate carbon mineralization for these systems.

Finally, the highest flood recorded in 2009 was a result of a La Niña event that occurred in 2008, when atypically higher values of precipitation were recorded (e.g. falling water 2008, Table 1). Integrated DOC photodegradation rates were $>2$-fold higher in the falling water period in 2009 than in the high water period in 2009 (Table 1), which should have resulted in a greater contribution of this process to the total DIC production in the water column. In this period, an atypically high level of solar radiation occurred due to a severe dry season caused by an El Niño event. This result suggests that the frequency and intensity of global climate events, such as El Niño, may deeply influence the DOC removal processes and DIC production in Amazonian aquatic ecosystems. It is important to report that our temporal resolution is limited, not covering more than one complete hydrological cycle, but that it was enough to show a trend in the importance of the high water period as a 'reset' period, dur- ing which substrates for DOC photodegradation and microbial degradation are renewed.

\section{CONCLUSIONS}

This seasonal investigation provides considerable insights into the interaction of light and bacteria with DOC degradation in Amazonian black water ecosystems. We confirmed our hypothesis that DOC degradation processes mediated by solar radiation and bacteria change throughout the hydrological cycle, altering their relative contribution to total DIC generation and total DOC removal. We conclude that temporal changes in the climate and in situ abiotic conditions associated with the flood pulse regulate the intensity of DOC photodegradation and its interaction with bacterial DOC removal (BP and BR). Besides its direct effect on DIC production in black water aquatic ecosystems, photodegradation was shown to have an extensive indirect effect on DIC production through stimulating BR. Together, these photo-induced biotic and abiotic processes may significantly impact the carbon dynamics of these systems. Better estimates of these processes which take spatial and temporal variations in this and other Amazonian freshwater ecosystems into consideration are needed to evaluate their overall contribution to the regional carbon balance. The high rates of total DOC mineralization (photo- and bacterial degradation) found during a severe El Niño event indicate the sensitivity of these systems to climate change and the need for long-term studies of these effects.

Acknowledgements. The authors are grateful to B. R. Forsberg, D. Kasper and H. Sarmento for comments on an early version of this manuscript and language review. Carbon analyses were performed in the Environmental Chemistry Laboratory at INPA, coordinated by H. Brandão da Cunha. Financial support was provided by Coordenação de Aperfeiçoamento de Pessoal de Nível Superior (CAPES) (ProcadNF Program) and Conselho Nacional de Desenvolvimento Científico e Tecnológico (CNPq) (Proc. 475961/2007-2 to V.F.F. and Project BioTupé to S.M.). J.H.F.A. and A.L.S. are grateful to CNPq for post-graduate scholarships, while V.F.F was partially supported by CNPq (Research productivity scholarship - Proc. 307490/2008-4).

\section{LITERATURE CITED}

Alin SR, Rasera M de FFL, Salimon CI, Richey JE, Holtgrieve GW, Krusche AV, Snidvongs A (2011) Physical controls on carbon dioxide transfer velocity and flux in low-gradient river systems and implications for regional carbon budgets. J Geophys Res 116:G01009, doi:10.1029/2010 JG001398 
Amado AM, Farjalla VF, Esteves FA, Bozelli RL, Roland F, Enrich-Prast A (2006) Complementary pathways of dissolved organic carbon removal pathways in clear-water Amazonian ecosystems: photochemical degradation and bacterial uptake. FEMS Microbiol Ecol 56:8-17

Amado AM, Cotner JB, Suhett AL, Esteves FA, Bozelli RL, Farjalla VF (2007) Contrasting interactions mediate dissolved organic matter decomposition in tropical aquatic ecosystems. Aquat Microb Ecol 49:25-34

> Amon RMW, Benner R (1996) Photochemical and microbial consumption of dissolved organic carbon and dissolved oxygen in the Amazon River system. Geochim Cosmochim Acta 60:1783-1792

Anesio AM, Graneli W, Aiken GR, Keiber DJ, Mopper K (2005) Effect of humic substance photodegradation on bacterial growth and respiration in lake water. Appl Environ Microbiol 71:6267-6275

> Benner R, Opsahl S, Chin-Leo G, Richey JE, Forsberg BR (1995) Bacterial carbon metabolism in the Amazon River system. Limnol Oceanogr 40:1262-1270

> Bertilsson S, Tranvik LJ (2000) Photochemical transformation of dissolved organic matter in lakes. Limnol Oceanogr 45:753-762

de Haan H (1993) Solar UV-light penetration and photodegradation of humic substances in peaty lake water. Limnol Oceanogr 38:1072-1076

Engle D, Melack JM (2000) Methane emissions from an Amazon floodplain lake: enhanced release during episodic mixing and during falling water. Biogeochemistry 51:71-90

Ertel JR, Hedges JI, Devol AH, Richey JE, Ribiero M de NG (1986) Dissolved humic substances of the Amazon River system. Limnol Oceanogr 31:739-754

Farjalla VF, Anesio AM, Bertilsson S, Granéli W (2001) Photochemical reactivity of aquatic macrophyte leachates: abiotic transformations and bacterial response. Aquat Microb Ecol 24:187-195

Farjalla VF, Azevedo DA, Esteves FA, Bozelli RL, Roland F, Enrich-Prast A (2006) Influence of hydrological pulse on bacterial growth and DOC uptake in a clear-water Amazonian lake. Microb Ecol 52:334-344

Farjalla VF, Amado AM, Suhett AL, Meirelles-Pereira F (2009) DOC removal paradigms in highly humic aquatic ecosystems. Environ Sci Pollut Res 16:531-538

Fearnside PM (1997) Greenhouse gases from deforestation in Brazilian Amazonia: net committed emissions. Clim Change 35:321-360

Franzinelli E, Igreja H (2002) Modern sedimentation in the Lower Negro River, Amazonas State, Brazil. Geomorphology 44:259-271

Fry JC (1990) Direct methods and biomass estimation. In: Grigorova R, Norris JR (eds) Techniques in microbial ecology. Academic Press, Waltham, p 41-85

Fry JC, Austin B (1988) Methods in aquatic bacteriology. Determination of biomass. John Wiley \& Sons, New York, NY

Granéli W, Lindell M, de Faria BM, Esteves F de A (1998) Photoproduction of dissolved inorganic carbon in temperate and tropical lakes - dependence on wavelength band and dissolved organic carbon concentration. Biogeochemistry 43:175-195

- Hedges JI, Cowie GL, Richey JE, Quay PD, Benner R, Strom M, Forsberg BR (1994) Origins and processing of organic matter in the Amazon River as indicated by carbohydrates and amino acids. Limnol Oceanogr 39:743-761
Hobbie JE, Daley RJ, Jasper S (1977) Use of nuclepore filters for counting bacteria by fluorescence microscopy. Appl Environ Microbiol 33:1225-1228

Houghton RA, Gloor M, Lloyd J, Potter C (2009) The regional carbon budget. In: Keller M, Bustamante M, Gash J, Silva Dias P (eds) Amazonia and global change. Geophysical Monograph Ser 186, American Geophysical Union, Washington DC, p 409-428

$\mathrm{Hu}$ C, Muller-Karger FE, Zepp RG (2002) Absorbance, absorption coefficient, and apparent quantum yield: a comment on common ambiguity in the use of these optical concepts. Limnol Oceanogr 47:1261-1267

> Huete AR, Didan K, Shimabukuro YE and others (2006) Amazon rainforests green-up with sunlight in dry season. Geophys Res Lett 33:L06405, doi:10.1029/2005 GL025583

Jardim WF, Bisinoti MC, Fadini PS, Silva D, Silverio G (2010) Mercury redox chemistry in the Negro River Basin, Amazon: the role of organic matter and solar light. Aquat Geochem 16:267-278

Jonsson A, Meili M, Bergström AK, Jansson M (2001) Whole-lake mineralization of allochthonous and autochthonous organic carbon in a large humic lake (Örträsket, N. Sweden). Limnol Oceanogr 46:1691-1700

Junk WJ, Bayley PB, Sparks RE (1989) The flood pulse concept in river-floodplain systems. Publ Spec Can Sci Halieut Aquat 106:110-127

Kemenes A, Forsberg BR, Melack JM (2007) Methane release below a tropical hydroelectric dam. Geophys Res Lett 34:L12809, doi:10.1029/2007GL029479

Latrubesse EM, Franzinelli E (2005) The late Quaternary evolution of the Negro River, Amazon, Brazil: implications for island and floodplain formation in large anabranching tropical systems. Geomorphology 70:372-397

Leenheer JA (1980) Origin and nature of humic substances in the waters of the Amazon River Basin. Acta Amazon 10:513-526

Massana R, Gasol JM, Bjørnsen PK and others (1997) Measurement of bacterial size via image analysis of epifluorescence preparations: description of an inexpensive system and solutions to some of the most common problems. Sci Mar 61:397-407

> Mayorga E, Aufdenkampe AK, Masiello CA and others (2005) Young organic matter as a source of carbon dioxide outgassing from Amazonian rivers. Nature 436: $538-541$

> Moreira-Turcq P, Seyler P, Guyot JL, Etcheber H (2003) Exportation of organic carbon from the Amazon River and its main tributaries. Hydrol Processes 17:1329-1344

> Nepstad DC, de Carvalho CR, Davidson EA and others (1994) The role of deep roots in the hydrological and carbon cycles of Amazonian forests and pastures. Nature 372:666-669

Obernosterer I, Benner R (2004) Competition between biological and photochemical processes in the mineralization of dissolved organic carbon. Limnol Oceanogr 49: $117-124$

Pullin MJ, Bertilsson S, Goldstone JV, Voelker BM (2004) Effects of sunlight and hydroxyl radical on dissolved organic matter: bacterial growth efficiency and production of carboxylic acids and other substrates. Limnol Oceanogr 49:2011-2022

Rai H, Hill G (1981) Bacterial biodynamics in Lago Tupé, central Amazonian water ria lake. Arch Hydrobiol 58: 420-468 
Rasera M de FFL (2010) Determinação dos fluxos de $\mathrm{CO}_{2} \mathrm{e}$ parâmetros físicos envolvidos neste processo em diferentes ambientes fluviais da Amazônia. PhD dissertation, University of São Paulo, Piracicaba

Remington S, Krusche A, Richey J (2011) Effects of DOM photochemistry on bacterial metabolism and $\mathrm{CO}_{2}$ evasion during falling water in a humic and a whitewater river in the Brazilian Amazon. Biogeochemistry 105: 185-200

Richey JE, Hedges JI, Devol AH, Quay PD, Victoria R, Martinelli L, Forsberg BR (1990) Biogeochemistry of carbon in the Amazon River. Limnol Oceanogr 35:352-371

Richey JE, Melack JM, Aufdenkampe AK, Ballester VM, Hess LL (2002) Outgassing from Amazonian rivers and wetlands as a large tropical source of atmospheric $\mathrm{CO}_{2}$. Nature 416:617-620

Rodríguez-Zúñiga UF, Milori DMBP, da Silva WTL, MartinNeto L, Oliveira LC, Rocha JC (2008) Changes in optical properties caused by UV-irradiation of aquatic humic substances from the Amazon River basin: seasonal vari- ability evaluation. Environ Sci Technol 42:1948-1953

Sioli H (1984) The Amazon. Dr W Junk Publishers, Dordrecht

> Suhett AL, Amado AM, Enrich-Prast A, Esteves F de A, Farjalla VF (2007) Seasonal changes of dissolved organic carbon photo-oxidation rates in a tropical humic lagoon: the role of rainfall as a major regulator. Can J Fish Aquat Sci 64:1266-1272

Theil-Nielsen J, Søndergaard M (1998) Bacterial carbon biomass calculated from biovolumes. Arch Hydrobiol 141: 195-207

- Tranvik LJ, Bertilsson S (2001) Contrasting effects of solar UV radiation on dissolved organic sources for bacterial growth. Ecol Lett 4:458-463

Vähätalo AV (2009) Light, photolytic reactivity and chemical products. In: Likens GE (ed) Encyclopedia of inland waters. Elsevier, Oxford, p 761-773

Wang X, Lou T, Xie H (2009) Photochemical production of dissolved inorganic carbon from Suwannee river humic acid. Chin J Oceanol Limnol 27:570-573

Submitted: October 12, 2012; Accepted: June 11, 2013

Proofs received from author(s): August 9, 2013
Editorial responsibility: Craig Carlson,

Santa Barbara, California, USA 